\title{
Characterization and Pathogenicity of Rhizoctonia Species on Canola
}

\author{
Ravjit K. Khangura, Agriculture Western Australia, Locked Bag No. 4, Bentley Delivery Center, South Perth, WA \\ 6983, Australia; Martin J. Barbetti, Agriculture Western Australia, Locked Bag No. 4, Bentley Delivery Center, \\ South Perth, WA 6983, Australia and Faculty of Agriculture, The University of Western Australia, Mounts Bay \\ Road, Nedlands, WA 6907, Australia; and Mark W. Sweetingham, Agriculture Western Australia, Locked Bag No. \\ 4, Bentley Delivery Center, South Perth, WA 6983, Australia
}

\begin{abstract}
Khangura, R. K., Barbetti, M. J., and Sweetingham, M. W. 1999. Characterization and pathogenicity of Rhizoctonia species on canola. Plant Dis. 83:714-721.

A total of 112 Rhizoctonia isolates were collected from various canola (Brassica napus) growing areas of Western Australia. Pectic enzyme electrophoresis differentiated these isolates into six distinct zymogram groups: $R$. solani, 54\% ZG5 (AG2-1), 8\% ZG6 (AG2-1), and 1\% ZG9 (AG10); binucleate Rhizoctonia, 12\% CZG1 (CAG1), 4\% CZG4, and 6\% CZG5 (AGK); and the remainder unidentified binucleate groups $(15 \%)$. Binucleate groups were also confirmed by fluorescent nuclear staining and hyphal morphology. One or more isolates from each of the above zymogram groups (including four unidentified binucleate groups) and an isolate of ZG1-1 (AG8) that causes bare patch in cereals and legumes were tested for their pathogenicity on canola. Isolates of ZG5 and ZG1-1 were highly pathogenic on canola, delayed seedling emergence, and caused severe hypocotyl and root rot, respectively. ZG5 also induced postemergence damping-off. Increasing the depth of sowing from 1 to $3 \mathrm{~cm}$ significantly delayed seedling emergence and increased disease severity. Four unidentified binucleate isolates (WAC9316, WAC9297, WAC9307, and WAC9290) were moderately pathogenic to canola, while two isolates (WAC9307 and WAC9316) caused significant preemergence damping-off. Two CZG5 isolates were weakly pathogenic. Isolates of ZG5 and ZG1-1 were also tested for their pathogenicity on other rotational crops (narrow-leafed lupin, subterranean clover, wheat, oats, barley, and mustard) and two weed species (wild radish and annual ryegrass). ZG5 caused a severe hypocotyl rot on mustard and mild symptoms of hypocotyl rot on narrow-leafed lupin and clover, but failed to infect any of the cereal hosts, such as wheat, oats, barley, and ryegrass. In contrast, all crops tested were highly susceptible to ZG1-1 except mustard, which was only moderately susceptible. Results indicate that ZG5 is most pathogenic to crucifers and is a mildly virulent pathogen of the leguminous crops but not of cereal crops tested. ZG1-1, known to cause bare patch in legumes and cereals, also can cause severe root rot in canola. This is the first report of hypocotyl rot and pathogenicity of ZG5 on canola in Australia.
\end{abstract}

Canola (Brassica napus L.) is now a major oilseed crop in Western Australia, with an estimated area of 510,000 ha sown in 1998. There has been a dramatic expansion in the area sown to canola since 1993, when only 35,000 ha were planted, and continued expansion is expected. Hypocotyl rot has been associated with poor or failed establishment of canola in Western Australia since 1994 (9). Symptoms of hypocotyl rot in young seedlings develop as dark brown water-soaked lesions at the base of the hypocotyl that later girdle the hypocotyl and progress upward. Generally the outer cells of the hypocotyl are degraded, making the hypocotyl very weak, thin, and unable to support the plant, which falls over. The degraded tissue may slough

Corresponding author: Ravjit Khangura

E-mail: rkhangura@agric.wa.gov.au

Accepted for publication 10 March 1999

Publication no. D-1999-0524-02R

(C) 1999 The American Phytopathological Society off, leaving the stele exposed, giving the hypocotyl a thin wire-like appearance (Fig. 1A). Similar symptoms are observed in plants up to 6 weeks old, with the leaves showing orange to purple coloration (Fig. 1C). Plants usually die if the lesions extend to two-thirds of the length of the hypocotyl. Preliminary studies indicated that Rhizoctonia spp. were associated with hypocotyl rot and damping-off of canola in Western Australia (9). Rhizoctonia solani Kühn is known to cause both preemergence and postemergence damping-off in crucifers and other crops $(1,4,8,10,16,22)$. In Canada, $R$. solani is reported to cause preemergence damping-off, postemergence seedling root rot, and brown girdling root rot of oilseed rape (B. campestris) and canola $(4,6,22)$. $R$. solani caused an annual yield loss of $30 \%$ in canola from the Peace River region of Alberta in Canada (20). The $R$. solani isolates from oilseed rape and canola in Western Canada are classed in anastomosis groups AG2-1 and AG4 $(6,22)$. Also, AG4 has been reported to cause seedling death in canola in Georgia, USA (1). In Indiana, widespread distribu- tion of AG2-1 causing crown rot on canola was reported during 1990-91, with losses due to this disease estimated at 8 to $12 \%$ on the basis of stand reductions (5). Damping-off of spring rape (B. napus and $B$. rapa) caused by $R$. solani was reported in $90 \%$ of the fields during 1981-82 in Finland (19). In Western Australia, bare patch of rapeseed (B. campestris) caused by $R$. solani AG-8 has been reported (10). To date, no information about Rhizoctonia strains causing hypocotyl rot on canola is available. This paper reports the characterization of Rhizoctonia isolates associated with hypocotyl and root rot of canola in Western Australia and their pathogenicity on canola, other rotational crop species, and weeds.

\section{MATERIALS AND METHODS}

Collection and isolation of Rhizoctonia species. During 1994 to 1996, isolates of Rhizoctonia were collected from canola crops in major canola growing areas of Western Australia (Fig. 2). Plants (3- to 5week-old) showing typical symptoms of damping-off were collected, and their roots were gently washed under running tap water (4 times) to remove adhering soil. The roots were then cut into $0.5-\mathrm{cm}$-long pieces and placed onto $2 \%$ water agar in petri dishes and incubated at $25^{\circ} \mathrm{C}$ for $48 \mathrm{~h}$. After $48 \mathrm{~h}$, colonies resembling Rhizoctonia were subcultured onto fresh potato dextrose agar (Gibco, BRL, Life Technologies, Paisle, Scotland) containing 10 ppm aureomycin hydrochloride (PDA+A). Later, hyphal tips from all Rhizoctonia-like colonies were transferred onto fresh $\mathrm{PDA}+\mathrm{A}$ and incubated at $25^{\circ} \mathrm{C}$.

Electrophoresis and pectic enzyme detection. Pectic zymogram groups of field isolates were identified using the method of Sweetingham et al. (17). An agar block (about $3 \times 3 \mathrm{~mm}^{2}$ ) from an actively growing colony of each isolate was transferred into a Bijoux bottle containing $2 \mathrm{ml}$ of a liquid medium with pectin as the only carbon source (17). After 9 days of incubation at $25^{\circ} \mathrm{C}$, the culture medium was analyzed electrophoretically. Culture fluids $(10 \mu \mathrm{l})$ were loaded into wells of $10 \%$ polyacrylamide gels. Electrophoresis was carried out at 2 to $3^{\circ} \mathrm{C}$ at $20 \mathrm{~mA}$ constant current for $10 \mathrm{~min}$. The gel was then incubated in $0.1 \mathrm{M}$ malic acid at $25^{\circ} \mathrm{C}$ for $1 \mathrm{~h}$, stained with aqueous 

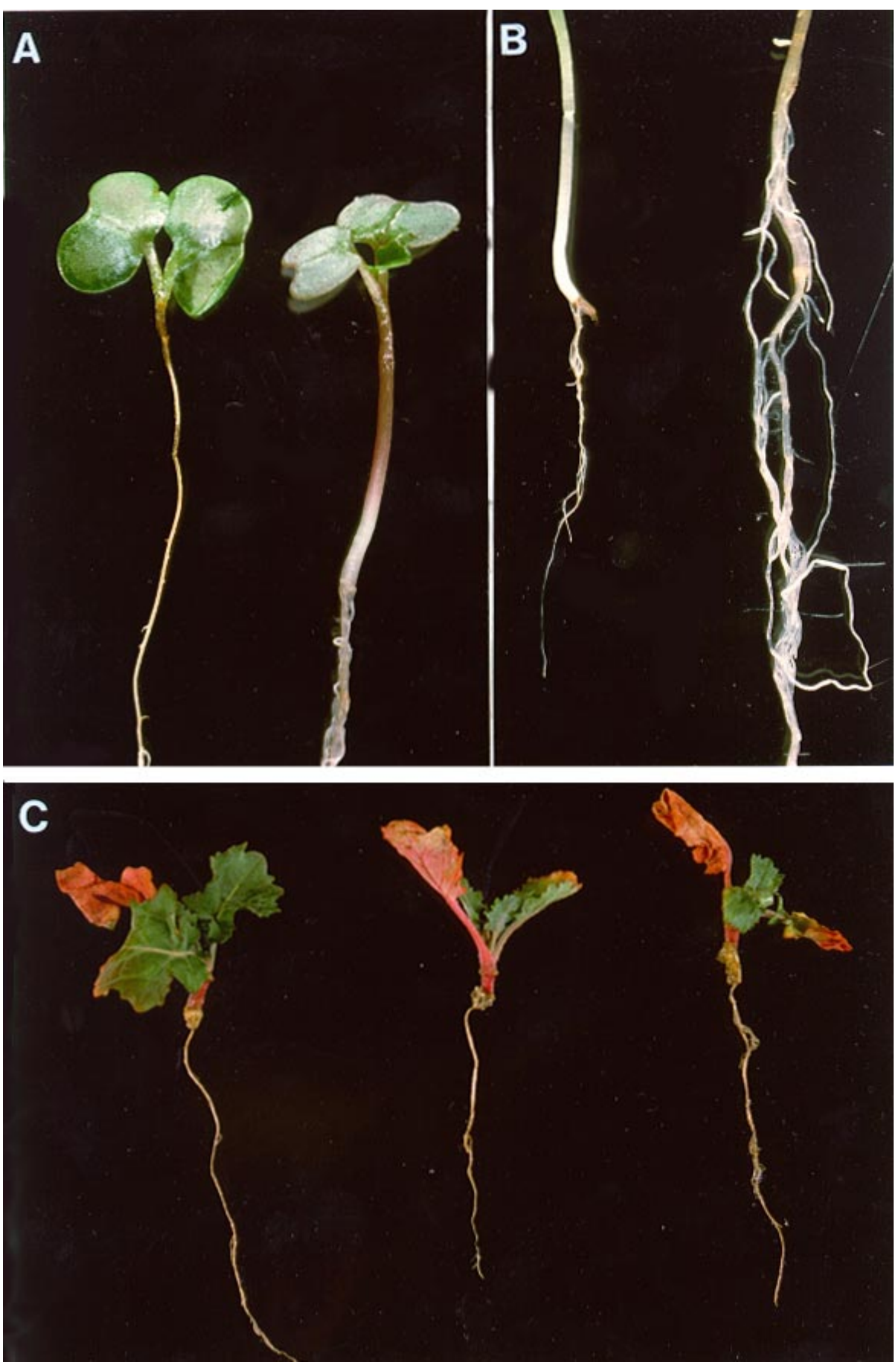

Fig. 1. Symptoms of hypocotyl and root rot in canola: (A) canola seedling showing thin wire-like appearance of the hypocotyl (left) and healthy seedling (right) in glasshouse experiments; (B) canola seedling showing severe root rot with ZG1-1 (left) and healthy seedling (right) in the glasshouse experiments; and (C) symptoms of hypocotyl rot on plants collected from the field. 
ruthenium red $(0.05 \%)$ overnight, and oxidized with ammonium persulfate $(0.1 \%)$ for $20 \mathrm{~min}$. A direct photographic print of the gel was made (under water) onto high-contrast black-and-white photographic paper (Ilfospeed 5.1M). Different zymogram groups were identified by comparing the isozyme patterns and $\mathrm{Rf}$ values of the unknown isolates with the known zymogram groups from previous work $(11,13,17)$.

Nuclear staining and hyphal diameter examination. The nuclei of the unidentified isolates were stained using the fluorescence staining method of Yang et al. (21). Hyphal diameters of unidentified isolates were measured according to the method of Carling et al. (2).

Pathogenicity of known zymogram groups of Rhizoctonia on canola (experiment 1). The pathogenicity of one isolate from each of the zymogram groups ZG5 (WAC8482), ZG6 (WAC8474), CZG1 (WAC8502), CZG4 (WAC8498), and CZG5 (R1959) from canola and an isolate of ZG1-1 (R2061), which causes bare patch in cereals and legumes, was tested on canola in a controlled environment phytotron cabinet. Inoculum was prepared by growing the test isolate on moist autoclaved millet seeds (Panicum miliaceum) for 2 weeks at $22^{\circ} \mathrm{C}$. Plastic pots $(9 \mathrm{~cm}$ diameter) of $1-\mathrm{kg}$ capacity were half-filled with soil mixture $(80 \%$ river sand:20\% yellow sand); then six millet seeds colonized by the respective Rhizoctonia isolate were placed on the soil surface, and the pot was filled with soil mixture. In our preliminary studies, we tested two, four, and six millet seeds colonized with each test isolate and found that six

Table 1. Number of Rhizoctonia isolates in each zymogram group isolated from each location ${ }^{\mathrm{a}}$

\begin{tabular}{lccccccc}
\hline Location & $\begin{array}{c}\text { ZG5 } \\
\text { (AG2-1) }\end{array}$ & $\begin{array}{c}\text { ZG6 } \\
\text { (AG2-1) }\end{array}$ & $\begin{array}{c}\text { ZG9 } \\
\text { (AG10) }\end{array}$ & $\begin{array}{c}\text { CZG1 } \\
\text { (CAG1) }\end{array}$ & CZG4 & $\begin{array}{c}\text { CZG5 } \\
\text { (AGK) }\end{array}$ & Unidentified \\
\hline Albany & 6 & 2 & $\ldots$ & 1 & $\ldots$ & 3 & 1 \\
Arthur River & 34 & 2 & $\ldots$ & $\ldots$ & 2 & 3 & 1 \\
Bodallin & 9 & $\ldots$ & $\ldots$ & $\ldots$ & $\ldots$ & $\ldots$ & $\ldots$ \\
Brookton & $\ldots$ & $\ldots$ & $\ldots$ & 8 & 1 & $\ldots$ & $\ldots$ \\
Callingiri & $\ldots$ & $\ldots$ & 1 & $\ldots$ & $\ldots$ & $\ldots$ & $\ldots$ \\
Hines Hill & 3 & $\ldots$ & $\ldots$ & $\ldots$ & $\ldots$ & $\ldots$ & $\ldots$ \\
Irwin & $\ldots$ & $\ldots$ & $\ldots$ & $\ldots$ & $\ldots$ & 1 & 2 \\
Katanning & $\ldots$ & $\ldots$ & $\ldots$ & $\ldots$ & $\ldots$ & $\ldots$ & 5 \\
Mingenew & $\ldots$ & $\ldots$ & $\ldots$ & $\ldots$ & $\ldots$ & 1 & 1 \\
Mount Barker & 6 & $\ldots$ & $\ldots$ & $\ldots$ & $\ldots$ & 1 & $\ldots$ \\
Nangeenan & $\ldots$ & $\ldots$ & $\ldots$ & $\ldots$ & $\ldots$ & $\ldots$ & $\ldots$ \\
Newdegate & $\ldots$ & $\ldots$ & $\ldots$ & 2 & $\ldots$ & $\ldots$ & $\ldots$ \\
Popanyinning & $\ldots$ & $\ldots$ & $\ldots$ & $\ldots$ & 1 & $\ldots$ & $\ldots$ \\
York & 2 & 5 & $\ldots$ & 2 & 1 & $\ldots$ & $\ldots$ \\
\hline
\end{tabular}

a $\ldots=$ groups not detected.

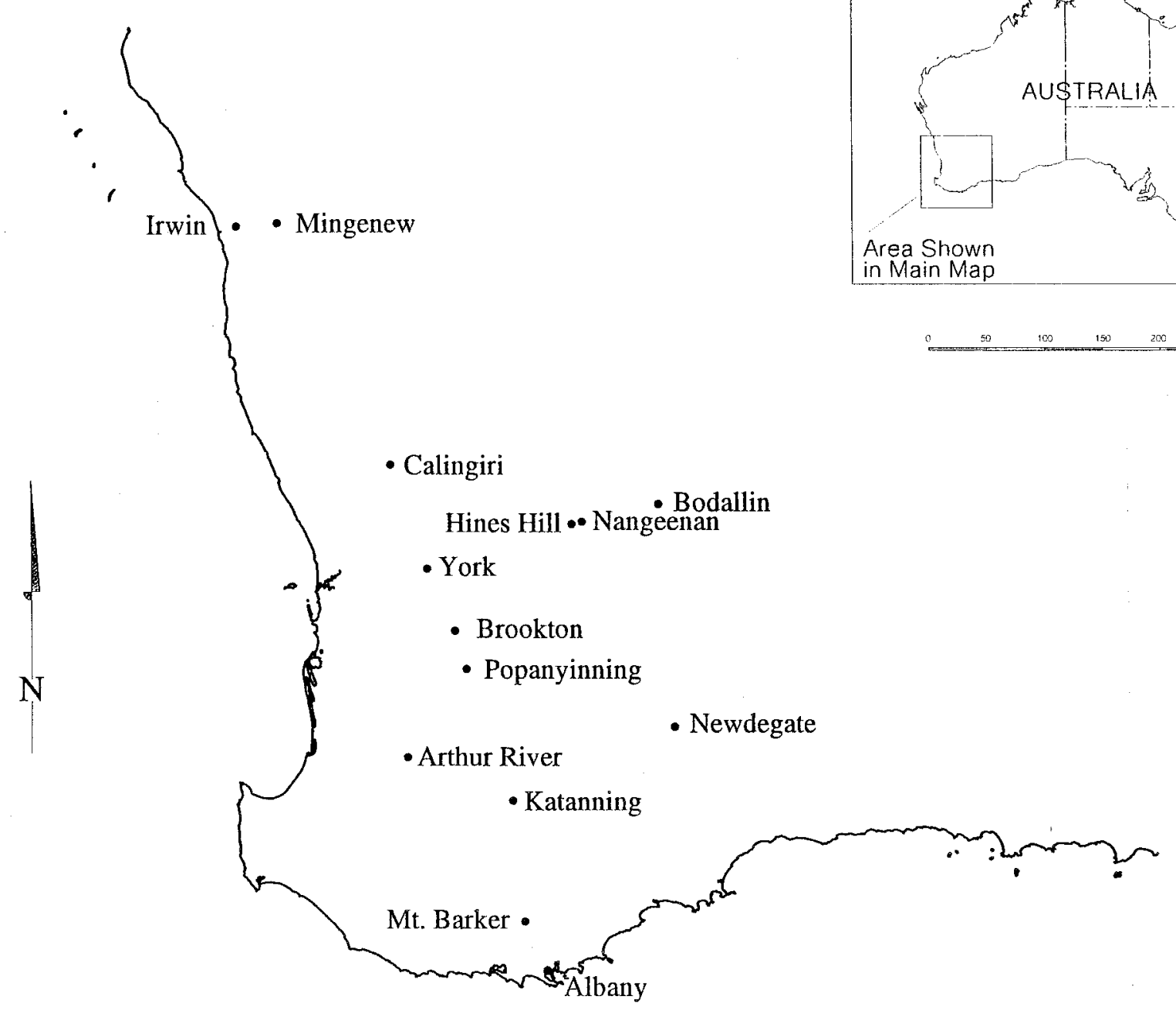

Fig. 2. Location of sites for collection of Rhizoctonia isolates from canola in Western Australia. 
millet seeds provided the optimum inoculum level for pathogenicity studies. Pots with sterile millet seeds were included as controls. Pots were maintained in a phytotron cabinet (Process Instrument and Controls, Pty. Ltd., Sydney, Australia) with day/night temperature of $18 / 15^{\circ} \mathrm{C}, 12-\mathrm{h}$ photoperiod, and light intensity of 300 $\mu \mathrm{E} / \mathrm{m}^{2} / \mathrm{s}$. The Rhizoctonia isolates were allowed to grow in the pots for 2 weeks on moist soil. The pots were watered to free drainage immediately after inoculation and then watered every 5 days. After 2 weeks, 12 surface-sterilized (70\% ethanol for 1 min) canola (B. napus) seeds cv. Oscar were sown in each pot at depths of 1,2 , or $3 \mathrm{~cm}$. A single pot with 12 seedlings constituted one experimental unit and was

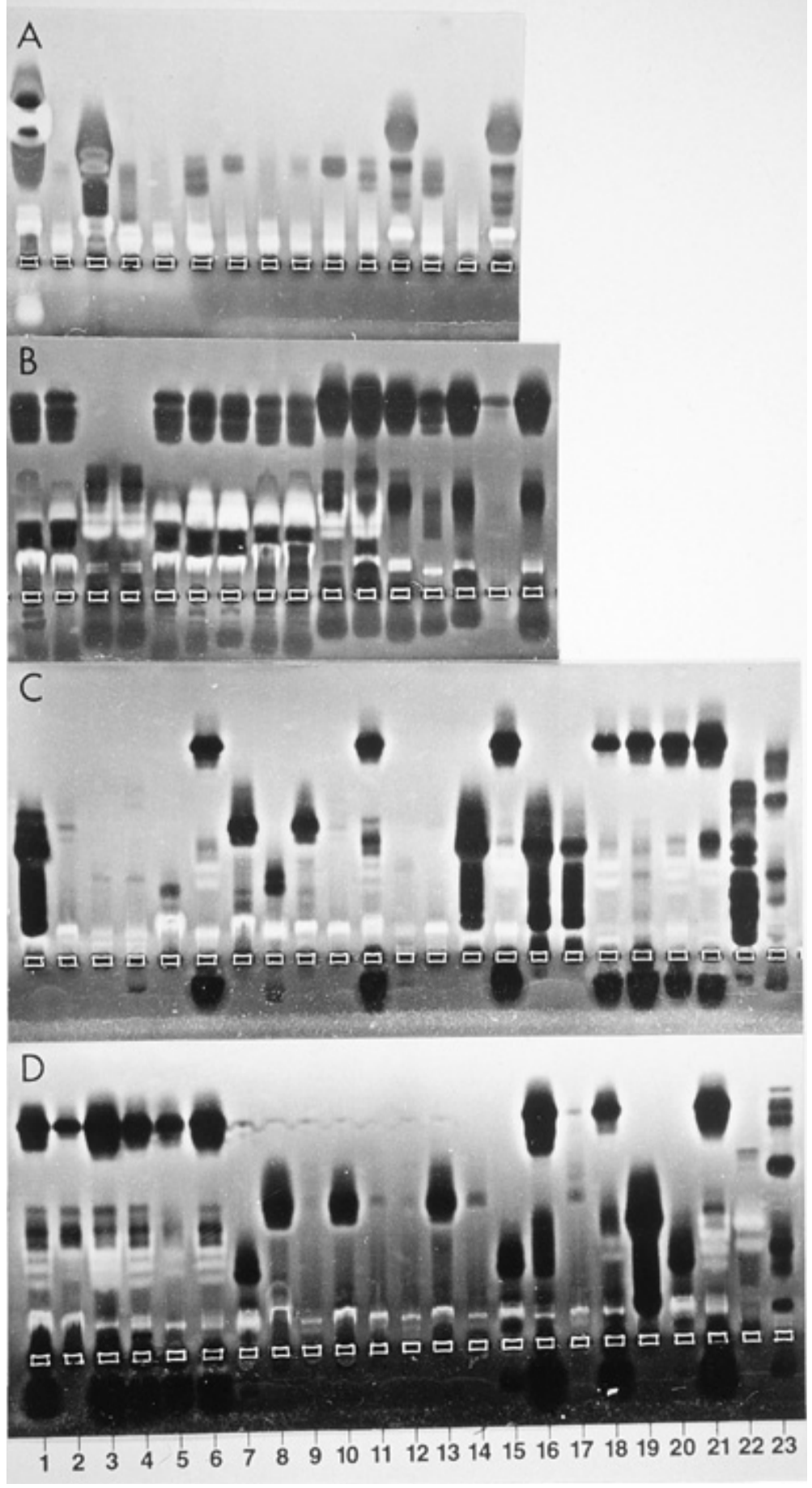

Fig. 3. Pectic zymograms of field isolates of Rhizoctonia. (A) lane 1, ZG9; lane 2, CZG1; lane 3, CZG5; lane 4, unidentified; lanes 5-11, CZG1; lane 12, CZG4; lanes 13-14, CZG1; lane 15, CZG4. (B) lanes 1-2, ZG6; lanes 3-4, ZG5; lanes 5-9, ZG6; lanes 10-16, ZG5. (C) lane 1, CZG5; lanes 2-5, unidentified; lane 6, ZG5; lanes 7-10, unidentified; lane 11, ZG5; lanes 12-13, unidentified; lane 14, CZG5; lane 15, ZG5; lanes 16-17, CZG5; lanes 18-20, ZG5; lane 21, known ZG5; lane 22, known ZG1-1; lane 23, known ZG3. (D) lanes 1-6, ZG5; lanes 7-15, unidentified; lane 16, ZG5; lane 17, unidentified; lane 18, ZG5; lane 19, CZG5; lane 20, unidentified; lane 21, known ZG5; lane 22, known ZG1-1; lane 23, known ZG3. replicated four times. Seedling emergence was first recorded 7 days after sowing, and final plant counts were recorded 14 days later. The roots were thoroughly washed and rated for hypocotyl rot on a 0 to 3 scale $(0=$ no lesions, $1=$ lesions on hypocotyl affecting $<25 \%$ of the length of the hypocotyl, 2 = lesions covering 26 to $75 \%$ of the length of the hypocotyl, $3=$ lesions covering $>75 \%$ of the length of the hypocotyl) and for taproot rot on a 0 to 5 scale $(0=$ no lesions, $1=$ small lesion on taproot, $2=$ necrosis up to $30 \%$ of taproot, $3=$ necrosis covering 31 to $60 \%$ of the taproot, 4 $=$ necrosis covering 61 to $99 \%$ of the taproot, $5=$ lesion completely severing taproot). Plants were also rated on a 0 to 5 scale for rot of lateral roots $(0=$ no lesions, $1=1$ lateral root girdled, $2=2$ to 5 lateral roots girdled, $3=6$ to 10 lateral roots girdled, $4=11$ to 15 lateral roots girdled, $5=$ $>15$ lateral roots girdled). Percent disease index was calculated as: $[\Sigma$ (no. plants in disease category) $\times$ (numerical value of disease category) $\times 100] /[$ (no. plants in all categories) $\times$ (maximum value on rating scale)].

Following disease assessments, three to five hypocotyl or root pieces with lesions were placed onto $2 \%$ water agar in petri dishes to reisolate the respective Rhizoctonia strains to fulfill Koch's postulates. This experiment was repeated to confirm pathogenicity.

In another experiment (experiment 1A), pathogenicity of ZG9 was tested along with ZG5 and ZG1-1 in a manner similar to that described above except that no measurements were made on seedling emergence.

Pathogenicity of unknown zymogram groups of Rhizoctonia on canola (experiment 2). Four isolates of Rhizoctonia (WAC9307, WAC9316, WAC9297, and WAC9290), each representing an unidentified binucleate group, and two isolates of CZG5 (WAC9308 and WAC9324) isolated from diseased canola seedlings were tested for their pathogenicity on canola cv. Narendra. The procedure was similar to that described above for experiment 1 , except that $0.1 \%$ (wt/wt) inoculum level (about 178 colonized millet seeds per $\mathrm{kg}$ of soil) was used, and canola seeds were sown $3 \mathrm{~cm}$ deep. The seedlings were rated for hypocotyl rot as described above (experiment 1).

Pathogenicity of ZG5 and ZG1-1 on rotational species and grasses (experiment 3). The pathogenicity of one isolate each of ZG1-1 and ZG5 was determined on seven crop species that are grown in rotation with canola: wheat (Triticum aestivum cv. Gamenya), barley (Hordeum vulgare cv. Yagan), oats (Avena sativa cv. Marloo), lupin (Lupinus angustifolius cv. Merrit), subterranean clover (Trifolium subterraneum cv. Goulburn), mustard (Brassica juncea Line 397-23), and canola (B. napus cv. Narendra) and two weed species: annual ryegrass (Lolium rigidum) 
and wild radish (Raphanus raphanistrum). The procedure for this experiment was similar to that of experiment 1 . The inoculum level was six colonized millet seeds per pot, and the seeds were sown 3 $\mathrm{cm}$ deep. The seedlings were rated for hypocotyl rot for ZG5 and for taproot rot for ZG1-1 at 21 days after sowing. The disease rating scales for cereals, grasses, and clover were based on those used by Sweetingham and MacNish (18), while for mustard and radish the same rating as described above (experiment 1) was used.

Experimental design and statistical analysis. A randomized complete block design with four replicates was used in each experiment. Data were analyzed by analysis of variance using Genstat 5 release 3.2 (Lawes Agricultural Trust, Rothamsted Experimental Station). Each experiment was analyzed separately. Experiment 1 was analyzed as a factorial design with effects due to isolate, depth, and isolate $\times$ depth interactions. Least significant differences (Fisher's protected LSD) were calculated following significant $F$ tests. In experiment 3 , there were significant differences in seed germination between hosts in the absence of Rhizoctonia. Therefore, to make comparisons among crops, emergence for each treatment was calculated as a percentage of the respective controls. Also, percent seedling emergence data were analyzed separately for crucifers (mustard, canola, radish), grasses (wheat, barley, oats, ryegrass), and legumes (lupin, clover). Data from experiments 1 and 2 could not be transformed to approximate normal distribution; therefore, emergence data for these experiments were analyzed without transformation. Percent disease index data from experiment 1 was $\log _{10}$ transformed and arcsine transformed for other experiments to approximate normality before analysis.

\section{RESULTS}

Pectic zymogram analysis. A total of 112 Rhizoctonia isolates were obtained from different canola growing areas of Western Australia during 1994 to 1996. In pectic zymogram investigations, $54 \%$ of the isolates belonged to ZG5 group, $8 \%$ to ZG6, $1 \%$ to ZG9, $12 \%$ to CZG1, $4 \%$ to CZG4, and $6 \%$ to CZG5. The remaining $15 \%$ of isolates were grouped under unidentified binucleate groups. The zymogram groups of the isolates from different locations and the number of isolates in each zymogram group are given in Table 1. Most isolates produced identical zymogram patterns (Fig. 3B, lanes 3-4, 10-16; Fig. 3C, lanes 6, 11, 15, 18-20; Fig. 3D, lanes 1-6, 16, 18). These isolates were all assigned to ZG5, as their zymogram patterns were identical to that of a known isolate of ZG5 (Fig. 3C and D, lane 21). The zymograms of other field isolates were identified as ZG6 (Fig. 3B, lanes 1-2, 5-9), ZG9 (Fig. 3A, lane 1), CZG1 (Fig. 3A, lanes 2, 4, 6-11, 13-14), CZG4 (Fig. 3A, lanes 12, 15), CZG5 (Fig. 3A, lane 3, Fig. 3C, lanes 1, 14, 16, Fig 3D, lane 19), and unidentified binucleate groups (Fig 3A, lane 5, Fig. 3C, lanes 2-5, 7-10, 12, 13, 17, Fig. 3D, lanes 7-15, 17, 20).

Nuclear staining and hyphal diameter examination. The nuclear staining of the four unknown (WAC9290, WAC9297, WAC9307, and WAC9316) and two known (WAC9308 and WAC9324) groups of CZG5 revealed that all these isolates were binucleate. The hyphal diameter observations exhibited that all the unknown isolates had narrow hyphae (3.75 to $6.25 \mu \mathrm{m}$ ) except WAC9307, which had hyphal diameter of the range of 5.0 to $7.5 \mu \mathrm{m}$.

Disease symptoms caused by $R$. solani, Rhizoctonia species, and unknown binucleate isolates. Three different types of symptoms were caused by the Rhizoctonia isolates tested: hypocotyl rot, taproot rot, and lateral root rot. Hypocotyl rot symptoms observed were dark brown watersoaked lesions on hypocotyls (Fig. 1A). Taproot rot symptoms were dark brown lesions, and in severe cases, the taproot

Table 2. Effect of different Rhizoctonia groups and sowing depths on seedling emergence ${ }^{\mathrm{a}}$ of canola cv. Oscar 7 days after sowing

\begin{tabular}{|c|c|c|c|c|c|}
\hline \multirow{2}{*}{\multicolumn{2}{|c|}{ Group }} & \multicolumn{4}{|c|}{ Percent seedling emergence 7 days after sowing } \\
\hline & & \multicolumn{3}{|c|}{ Sowing depths $(\mathrm{cm})$} & \multirow[b]{2}{*}{ Mean } \\
\hline Zymogram & Anastomosis & 1 & 2 & 3 & \\
\hline ZG1-1 & AG8 & 69 & 73 & 35 & 59 \\
\hline ZG5 & AG2-1 & 73 & 75 & 34 & 61 \\
\hline ZG6 & AG2-1 & 88 & 75 & 52 & 74 \\
\hline CZG1 & CAG1 & 83 & 63 & 67 & 71 \\
\hline CZG4 & & 71 & 80 & 88 & 83 \\
\hline CZG5 & AGK & 90 & 83 & 84 & 86 \\
\hline \multirow{2}{*}{ Control } & & 85 & 79 & 79 & 81 \\
\hline & Mean & 80 & 78 & 63 & \\
\hline \multicolumn{6}{|l|}{$\operatorname{LSD}(P<0.05)$} \\
\hline Depth & 8 & & & & \\
\hline Group & 12 & & & & \\
\hline Depth $\times$ group & 21 & & & & \\
\hline
\end{tabular}

${ }^{a}$ Mean of four replicates and based upon number of emerging seedlings of 12 seeds planted per pot in each replicate. was completely severed or absent (Fig. 1B). Lateral root rot symptoms were pale brown to dark brown lesions which, when severe, girdled the roots. The ZG5 isolate predominantly caused hypocotyl rot with minor taproot and lateral root rot and postemergence damping-off. The ZG1-1 isolate predominantly caused taproot and lateral root rots but also caused mild hypocotyl rot. In pots, ZG1-1 infected plants remained stunted. The isolates ZG6, ZG9, and CZG5 (binucleate Rhizoctonia) only caused mild symptoms of hypocotyl, taproot, and lateral root rots. Unidentified binucleate isolates caused hypocotyl and taproot rots and mild lateral root rot.

Pathogenicity of Rhizoctonia isolates on canola. Seedling emergence. In the first experiment, seedling emergence counts 7 days after sowing indicated that increasing the depth of sowing significantly reduced seedling emergence (Table 2). With ZG5, seedling emergence was significantly $(P<$ 0.05 ) reduced by $58 \%$ when seeds were sown at a depth of $3 \mathrm{~cm}$ compared with seed sown at 1 and $2 \mathrm{~cm}(15$ and $12 \%$, respectively) and the uninoculated control. Likewise, with ZG1-1, the percent seedling emergence was significantly $(P<0.05)$ reduced by $55 \%$ when plants were sown 3 cm deep compared with 1 and $2 \mathrm{~cm}$ (20 and $15 \%$, respectively) and the uninoculated control. ZG6 significantly reduced seedling emergence when plants were seeded at 3-cm depth compared with 1 and $2 \mathrm{~cm}$ depth of sowing seeds and the control. In contrast, CZG1, CZG4, and CZG5 isolates did not affect seedling emergence irrespective of depth of sowing.

In the second experiment, seedling emergence was significantly reduced by 59 and $41 \%$ with isolates WAC9307 and WAC9316, respectively, compared with other isolates and control, which had $96 \%$ emergence (Table 3). Percent seedling emergence in other isolates (WAC9297, WAC9308,

Table 3. Effect of different unidentified Rhizoctonia isolates on percent seedling emergence $^{\mathrm{a}}$ and percent disease index $(\mathrm{PDI})^{\mathrm{b}}$ of canola

\begin{tabular}{lcc}
\hline Isolate & $\begin{array}{c}\text { Seedling } \\
\text { emergence (\%) }\end{array}$ & PDI \\
\hline WAC 9307 & 40 & $39(38.7)$ \\
WAC 9316 & 56 & $44(41.1)$ \\
WAC 9297 & 79 & $41(39.5)$ \\
WAC 9290 & 90 & $38(37.6)$ \\
WAC 9308 & 81 & $7(14.5)$ \\
WAC 9324 & 94 & $5(12.7)$ \\
Control & 96 & $0(0)$ \\
LSD $(P<0.01)$ & 24 & $(9)$ \\
\hline${ }^{a}$ Mean of four replicates and based upon num- \\
ber of emerging seedlings of 12 seeds planted \\
per pot in each replicate. \\
b Mean of four replicates and calculated as: \\
[ $\Sigma$ (no. plants in disease category) $\times$ \\
(numerical value of disease category) $\times 100] /$ \\
[(no. plants in all categories) $\times$ (maximum \\
value on rating scale)]. Figures within paren- \\
theses are arcsine transformed means.
\end{tabular}


WAC9290, and WAC9324) varied between 79 and $94 \%$ and was not significantly different from each other or the control.

In the third experiment, seedling emergence was significantly reduced with ZG5 by 60,72 , and $100 \%$ in $B$. juncea, $B$. napus, and $R$. raphanistrum, respectively, compared with their respective controls was no effect of seedling emergence with either ZG5 or ZG1-1 except in T. aestivum, where seedling emergence was significantly reduced by $64 \%$ with the ZG1-1 isolate compared to its control.

Disease index. In all the above experiments, there were no disease symptoms in control seedlings grown in uninfested soil mixture. All the isolates tested produced varying degrees of disease on canola (Table 5) in experiment 1. Hypocotyl rot was significantly $(P<0.05)$ higher with ZG5 at the 3-cm sowing depth compared to $1 \mathrm{~cm}$. ZG1-1 also caused some hypocotyl rot, but the percent disease index was not affected by sowing depth, with this group producing moderate disease indices for all (Table 4). However, in other hosts, there

depths of sowing. Binucleate groups CZG1, CZG4, and CZG5 and multinucleate group ZG6 resulted in very low hypocotyl rot indices and were not affected by the depth of sowing in all these groups, except that with ZG6, the hypocotyl rot significantly increased when it was sown at 2 and $3 \mathrm{~cm}$ rather than at $1 \mathrm{~cm}$.

ZG1-1 induced high levels of taproot and lateral root rot but was not influenced by sowing depth. The isolate ZG5 caused more disease on lateral roots when plants were seeded at a depth of $3 \mathrm{~cm}$ than at 1 and $2 \mathrm{~cm}$ (Table 5). Only ZG5 caused postemergent damping-off, which was not affected by sowing depths.

In experiment $1 \mathrm{~A}$, a significantly lower level of hypocotyl rot was observed with ZG9 and ZG1-1 compared with ZG5. Likewise, lower levels of taproot rot were observed with ZG9 and ZG5 compared with ZG1-1. However, the disease indices of hypocotyl and taproot rot with ZG9 were significantly higher for plants sown at 2 or $3 \mathrm{~cm}$ compared to $1 \mathrm{~cm}$ sowing depth (Table 6). Both ZG5 and ZG1-1 caused

Table 4. Effect of different Rhizoctonia groups on percent seedling emergence ${ }^{\mathrm{a}}$ of various hosts

\begin{tabular}{lccrc}
\hline & \multicolumn{3}{c}{ Percent seedling emergence } \\
\cline { 2 - 5 } Host & ZG1-1 (AG8) & ZG5 (AG2-1) & Control & LSD $(\boldsymbol{P}<\mathbf{0 . 0 1})$ \\
\hline Lupinus angustifolius & $83(66)$ & $79(63)$ & $79(63)$ & $(8)$ \\
Trifolium subterraneum & $73(59)$ & $74(65)$ & $84(67)$ & $(8)$ \\
Brassica juncea & $94(80)$ & $40(35)$ & $100(90)$ & $(32)$ \\
B. napus & $77(62)$ & $27(27)$ & $96(82)$ & $(32)$ \\
Raphanus raphanistrum & $40(39)$ & $0(0)$ & $59(51)$ & $(32)$ \\
Triticum aestivum & $19(22)$ & $29(32)$ & $52(46)$ & $(15)$ \\
Avena sativa & $61(51)$ & $68(55)$ & $54(47)$ & $(15)$ \\
Hordeum vulgare & $94(80)$ & $92(76)$ & $98(86)$ & $(15)$ \\
Lolium rigidum & $50(45)$ & $44(41)$ & $50(45)$ & $(15)$ \\
\hline
\end{tabular}

${ }^{a}$ Mean of four replicates and based upon number of emerging seedlings of 12 seeds planted per pot in each replicate. Figures within parentheses are arcsine transformed means. severe hypocotyl and root rots, respectively. A similar trend was observed with regard to the effect of sowing depth on pathogenicity of these two isolates, as in experiment 1 (Table 6).

In experiment 2 , disease indices varied for the different unidentified binucleate $R h i$ zoctonia groups (Table 3). While isolate WAC9316 produced the highest disease index (44\%), followed by isolates WAC9297, WAC9307, and WAC9290, with disease indices of 40,39 , and $38 \%$, respectively, but these differences were not significant. Isolates WAC9324 and WAC9308 were only weakly pathogenic, with low disease indices of 5 and $7 \%$, respectively.

In experiment 3 , the pathogenicity of ZG5 and ZG1-1 varied greatly, depending on the crop and weed species tested (Fig. 4). For ZG5, the disease index value was significantly higher $(79 \%)$ in $B$. juncea than in B. napus (51\%), lupin (21\%), and clover $(16 \%)$. The cereal crop and grass weed species tested were not damaged by ZG5. With ZG1-1, the disease index was significantly lower in $B$. juncea $(29 \%)$ than in lupin $(53 \%)$, wild radish $(54 \%)$, or $B$. napus $(56 \%)$. In clover and grass species, the disease indices were higher, ranging between 74 and $100 \%$.

Reisolation of Rhizoctonia isolates from lesions was successful in all pathogenicity tests of experiments $1,1 \mathrm{~A}, 2$, and 3 .

\section{DISCUSSION}

$R$. solani is an important pathogen of field crops in Australia (11,13,17). Using electrophoresis studies of pectic enzyme patterns, 14 different isozyme groups of multinucleate $R$. solani, 5 distinct groups of binucleate Rhizoctonia-like species, and

Table 5. Effect of different Rhizoctonia groups and sowing depths on hypocotyl, taproot, and lateral root rot of canola cv. Oscar

\begin{tabular}{|c|c|c|c|c|c|c|c|c|c|c|c|c|c|}
\hline & & \multicolumn{12}{|c|}{ Percent disease index ${ }^{a}$} \\
\hline \multicolumn{2}{|c|}{ Group } & \multicolumn{4}{|c|}{ Hypocotyl rot } & \multicolumn{4}{|c|}{ Taproot rot } & \multicolumn{4}{|c|}{ Lateral root rot } \\
\hline $\mathbf{Z G}^{\mathbf{b}}$ & $\mathbf{A G}^{\mathbf{c}}$ & $1 \mathrm{~cm}$ & $2 \mathrm{~cm}$ & $3 \mathrm{~cm}$ & Mean & $1 \mathrm{~cm}$ & $2 \mathrm{~cm}$ & $3 \mathrm{~cm}$ & Mean & $1 \mathrm{~cm}$ & $2 \mathrm{~cm}$ & $3 \mathrm{~cm}$ & Mean \\
\hline ZG1-1 & AG8 & $\begin{array}{c}2.9 \\
(0.5)\end{array}$ & $\begin{array}{c}4.9 \\
(0.7)\end{array}$ & $\begin{array}{c}7.9 \\
(0.9)\end{array}$ & $\begin{array}{c}5.9 \\
(0.4)\end{array}$ & $\begin{array}{l}28.0 \\
(1.5)\end{array}$ & $\begin{array}{l}37.7 \\
(1.6)\end{array}$ & $\begin{array}{l}42.0 \\
(1.6)\end{array}$ & $\begin{array}{l}30.3 \\
(1.4)\end{array}$ & $\begin{array}{l}27.9 \\
(1.5)\end{array}$ & $\begin{array}{l}35.2 \\
(1.6)\end{array}$ & $\begin{array}{c}28.4 \\
(1.45)\end{array}$ & $\begin{array}{l}23.5 \\
(1.3)\end{array}$ \\
\hline ZG5 & AG2-1 & $\begin{array}{c}8.3 \\
(0.9)\end{array}$ & $\begin{array}{l}26.4 \\
(1.4)\end{array}$ & $\begin{array}{l}41.0 \\
(1.6)\end{array}$ & $\begin{array}{l}23.8 \\
(1.0)\end{array}$ & $\begin{array}{c}1.5 \\
(0.2)\end{array}$ & $\begin{array}{c}2.9 \\
(0.5)\end{array}$ & $\begin{array}{l}7.5 \\
(0.9)\end{array}$ & $\begin{array}{l}7.2 \\
(0.5)\end{array}$ & $\begin{array}{c}2.7 \\
(0.4)\end{array}$ & $\begin{array}{c}2.7 \\
(0.4)\end{array}$ & $\begin{array}{c}6.0 \\
(0.8)\end{array}$ & $\begin{array}{c}5.2 \\
(0.4)\end{array}$ \\
\hline ZG6 & AG2-1 & $\begin{array}{c}0.9 \\
(-0.02)\end{array}$ & $\begin{array}{c}4.9 \\
(0.7)\end{array}$ & $\begin{array}{l}5.0 \\
(0.7)\end{array}$ & $\begin{array}{c}2.5 \\
(0.2)\end{array}$ & $\begin{array}{c}0.95 \\
(-0.02)\end{array}$ & $\begin{array}{c}0.9 \\
(-0.06)\end{array}$ & $\begin{array}{l}1.9 \\
(0.3)\end{array}$ & $\begin{array}{l}1.9 \\
(0.2)\end{array}$ & $\begin{array}{c}0.8 \\
(-0.08)\end{array}$ & $\begin{array}{c}0.8 \\
(-0.08)\end{array}$ & $\begin{array}{c}0.8 \\
(-0.08)\end{array}$ & $\begin{array}{c}0.8 \\
(-0.08)\end{array}$ \\
\hline CZG1 & CZG1 & $\begin{array}{c}0.8 \\
(-0.10)\end{array}$ & $\begin{array}{l}1.6 \\
(0.2)\end{array}$ & $\begin{array}{c}2.3 \\
(0.4)\end{array}$ & $\begin{array}{c}1.6 \\
(0.08)\end{array}$ & $\begin{array}{l}1.52 \\
(0.2)\end{array}$ & $\begin{array}{c}1.3 \\
(0.1)\end{array}$ & $\begin{array}{c}3.0 \\
(0.5)\end{array}$ & $\begin{array}{c}3.2 \\
(0.4)\end{array}$ & $\begin{array}{c}0.8 \\
(-0.08)\end{array}$ & $\begin{array}{c}0.8 \\
(-0.08)\end{array}$ & $\begin{array}{c}0.8 \\
(-0.08)\end{array}$ & $\begin{array}{c}0.8 \\
(-0.08)\end{array}$ \\
\hline CZG4 & & $\begin{array}{c}1.3 \\
(-0.1)\end{array}$ & $\begin{array}{c}0.8 \\
(-0.1)\end{array}$ & $\begin{array}{c}1.7 \\
(0.2)\end{array}$ & $\begin{array}{c}1.4 \\
(0.08)\end{array}$ & $\begin{array}{l}1.79 \\
(0.3)\end{array}$ & $\begin{array}{l}2.8 \\
(0.4)\end{array}$ & $\begin{array}{l}9.1 \\
(0.9)\end{array}$ & $\begin{array}{l}5.1 \\
(0.5)\end{array}$ & $\begin{array}{c}0.8 \\
(-0.08)\end{array}$ & $\begin{array}{c}0.8 \\
(-0.08)\end{array}$ & $\begin{array}{c}0.8 \\
(-0.08)\end{array}$ & $\begin{array}{c}0.8 \\
(-0.08)\end{array}$ \\
\hline CZG5 & AGK & $\begin{array}{c}0.8 \\
(-0.10)\end{array}$ & $\begin{array}{c}0.9 \\
(-0.02)\end{array}$ & $\begin{array}{l}1.6 \\
(0.2)\end{array}$ & $\begin{array}{c}1.4 \\
(0.05)\end{array}$ & $\begin{array}{l}4.92 \\
(0.7)\end{array}$ & $\begin{array}{c}4.4 \\
(0.6)\end{array}$ & $\begin{array}{c}7.5 \\
(0.8)\end{array}$ & $\begin{array}{c}7.2 \\
(0.5)\end{array}$ & $\begin{array}{c}0.8 \\
(-0.08)\end{array}$ & $\begin{array}{c}0.8 \\
(-0.08)\end{array}$ & $\begin{array}{c}0.8 \\
(-0.08)\end{array}$ & $\begin{array}{c}0.8 \\
(-0.08)\end{array}$ \\
\hline & Mean & $\begin{array}{c}2.5 \\
(0.05)\end{array}$ & $\begin{array}{c}5.1 \\
(0.3)\end{array}$ & $\begin{array}{l}10.7 \\
(0.6)\end{array}$ & & $\begin{array}{c}6.7 \\
(0.4)\end{array}$ & $\begin{array}{l}9.7 \\
(0.6)\end{array}$ & $\begin{array}{l}12.3 \\
(0.8)\end{array}$ & & $\begin{array}{c}3.6 \\
(0.07)\end{array}$ & $\begin{array}{c}5.6 \\
(0.10)\end{array}$ & $\begin{array}{c}6.8 \\
(0.18)\end{array}$ & \\
\hline $\begin{array}{l}\text { LSD } \\
(P<0.05)\end{array}$ & $\begin{array}{l}\text { Depth } \\
\text { Group } \\
\text { Depth } \times \\
\text { group }\end{array}$ & $\begin{array}{l}(0.12) \\
(0.17) \\
(0.52)\end{array}$ & & & & $\begin{array}{l}(0.12) \\
(0.18) \\
(0.54)\end{array}$ & & & & $\begin{array}{l}(0.08) \\
(0.10) \\
(0.30)\end{array}$ & & & \\
\hline
\end{tabular}

\footnotetext{
${ }^{a}$ Mean of four replicates and calculated as: [ $\Sigma$ (no. plants in disease category) $\times($ numerical value of disease category $\left.) \times 100\right] /[($ no. plants in all categories $)$ $\times$ (maximum value on rating scale)]. Figures within parentheses are $\log _{10}$ transformations; there was no disease in the noninfested control.

b Zymogram group.

${ }^{\mathrm{c}}$ Anastomosis group.
} 
1 group with Waitea teleomorph have already been described from Australia $(11,13,17)$. Five zymogram groups (ZG1-1 to ZG1-5) of AG-8 are reported to cause bare patch of cereals and legumes across Australia $(14,17)$. Zymogram groups ZG5 and ZG6 both belong to AG2-1, and ZG6 is reported to cause hypocotyl and root rot of legumes in Western and South Australia (11). However, binucleate groups like CZG1, CZG4, CZG5, and those from cereals and legumes in Western and South Australia were not pathogenic on these hosts. The anastomosis groups of CZG1 and CZG5 are CAG-1 and AGK, respectively (3).

Pectic enzyme patterns of the 112 Rhizoctonia isolates collected in this study from canola-growing areas of Western Australia represented six distinct zymogram groups and four unidentified binucleate groups, as confirmed by fluorescence nuclear staining. The dominant $\mathrm{ZG}$ isolated from diseased canola seedlings was ZG5, as it accounted for $54 \%$ of isolates and was highly pathogenic on canola and caused postemergence damping-off (Fig. 1A). ZG5 has not been reported previously to be pathogenic on canola in Australia.

In Canada and the United States, AG2-1 and AG4 are the two principal AGs causing damping-off of seedlings and mature plant root rot (brown girdling root rot) in oilseed rape and canola (20). There, AG2-1 isolates mainly attack seedlings and AG4 isolates mainly attack adult plants and cause basal stem rot $(7,20)$. The zymogram group(s) of Canadian AG2-1 isolates is not known. In Australia, isolates of ZG5 have been collected and characterized from soil, Rapistrum sp., and wheat in South Australia and assigned to AG2-1 (14). ZG5 isolates were also reported from wheat and lupin in Western Australia (17) and were attributed to AG21 (11). However, none of these ZG5 isolates were tested for their pathogenicity on canola. In our study, neither AG4 nor ZG1-1 (AG8) was isolated from diseased canola seedlings, but ZG1-1 (AG8) was included in the pathogenicity studies because it is known to cause bare patch in cereals and legumes in Western Australia. Our results show that there was considerable variation in the pathogenicity among canola isolates in Australia, from highly virulent (ZG5, ZG1-1) to intermediate unidentified (WAC9316, WAC9307, WAC9297, WAC9290), compared to weakly virulent isolates of ZG6, ZG9, CZG1, CZG4, and CZG5. Similar results have also been reported with binucleate strains on cereals and legumes from Australia (17). ZG1-1 was also highly pathogenic on canola and not only caused root rot but also caused hypocotyl rot. In our study, an isolate of ZG6 appeared to be weakly virulent on canola, and in the future, more isolates of ZG6 may need to be tested to determine the virulence of these isolates since we tested only one isolate of this group.

Although isolates representing CZG1, CZG4, and CZG5 were weakly pathogenic on canola, four as yet unidentified binucleate groups were found to be pathogenic in our tests at inoculum level of $0.1 \%$, which was higher than that needed for high pathogenicity of multinucleate ZG5 and ZG1-1. In our experiments, the isolates of CZG5, even at $0.1 \%$ inoculum level, did not reduce emergence significantly and were very weakly pathogenic to canola. In contrast, a study from the United States indicated that all isolates of AG-K (CZG5) caused high levels of preemergence damping-off of rapeseed (15). However, in those studies, rapeseed seed was placed directly on mycelium of AG-K, and it appears that only at these very high levels of inoculum can AG-K cause substantial preemergence damping-off of rapeseed.

In one of our experiments, increasing the depth of sowing to $3 \mathrm{~cm}$ delayed seedling emergence in the presence of ZG1-1 and ZG5 compared with 1 and $2 \mathrm{~cm}$ depth of sowing; whereas the isolates WAC9316 and WAC9307 substantially reduced the

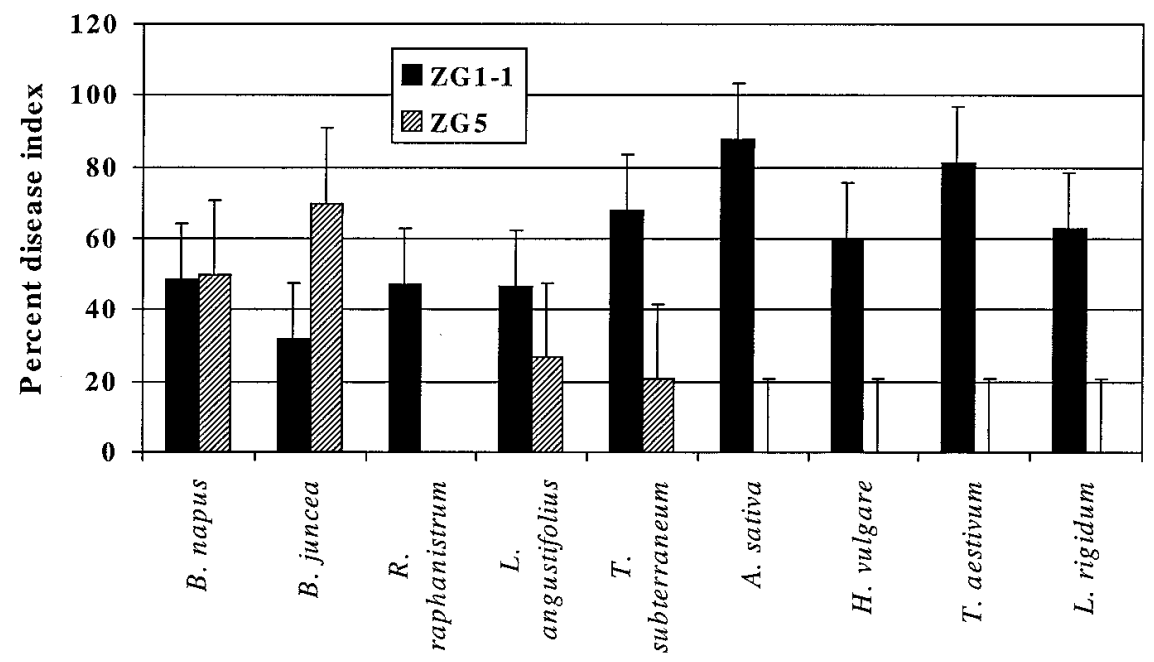

Fig. 4. Percent disease index of various host species caused by Rhizoctonia isolates of ZG1-1 and ZG5. There was no disease in the noninfested controls, and percent disease index was calculated as: $[\Sigma$ (no. plants in disease category) $\times($ numerical value of disease category $) \times 100] /[$ (no. plants in all categories $) \times($ maximum value on rating scale $)]$.

Table 6. Effect of different Rhizoctonia zymogram groups and sowing depths on hypocotyl, taproot, and lateral root rot of canola cv. Oscar

\begin{tabular}{|c|c|c|c|c|c|c|c|c|c|c|c|c|c|}
\hline & & \multicolumn{12}{|c|}{ Percent disease index ${ }^{a}$} \\
\hline \multicolumn{2}{|c|}{ Group } & \multicolumn{4}{|c|}{ Hypocotyl rot } & \multicolumn{4}{|c|}{ Taproot rot } & \multicolumn{4}{|c|}{ Lateral root rot } \\
\hline ZG & AG & $1 \mathrm{~cm}$ & $2 \mathrm{~cm}$ & $3 \mathrm{~cm}$ & Mean & $1 \mathrm{~cm}$ & $2 \mathrm{~cm}$ & $3 \mathrm{~cm}$ & Mean & $1 \mathrm{~cm}$ & $2 \mathrm{~cm}$ & $3 \mathrm{~cm}$ & Mean \\
\hline ZG5 & AG2-1 & $\begin{array}{c}17 \\
(24)\end{array}$ & $\begin{array}{c}54 \\
(47)\end{array}$ & $\begin{array}{c}85 \\
(75)\end{array}$ & $\begin{array}{c}52 \\
(48)\end{array}$ & $\begin{array}{c}4 \\
(9)\end{array}$ & $\begin{array}{c}6 \\
(14)\end{array}$ & $\begin{array}{c}10 \\
(18)\end{array}$ & $\begin{array}{c}7 \\
(14)\end{array}$ & $\begin{array}{c}2 \\
(4)\end{array}$ & $\begin{array}{c}10 \\
(18)\end{array}$ & $\begin{array}{c}16 \\
(23)\end{array}$ & $\begin{array}{c}9 \\
(15)\end{array}$ \\
\hline ZG1-1 & AG8 & $\begin{array}{c}0 \\
(0)\end{array}$ & $\begin{array}{c}6 \\
(12)\end{array}$ & $\begin{array}{c}12 \\
(19)\end{array}$ & $\begin{array}{c}6 \\
(10)\end{array}$ & $\begin{array}{l}37 \\
(37)\end{array}$ & $\begin{array}{c}40 \\
(39)\end{array}$ & $\begin{array}{l}53 \\
(47)\end{array}$ & $\begin{array}{c}43 \\
(41)\end{array}$ & $\begin{array}{c}36 \\
(37)\end{array}$ & $\begin{array}{c}37 \\
(37)\end{array}$ & $\begin{array}{c}44 \\
(42)\end{array}$ & $\begin{array}{c}39 \\
(38)\end{array}$ \\
\hline ZG9 & AG10 & $\begin{array}{c}0 \\
(0)\end{array}$ & $\begin{array}{c}10 \\
(18)\end{array}$ & $\begin{array}{c}16 \\
(23)\end{array}$ & $\begin{array}{c}9 \\
(14)\end{array}$ & $\begin{array}{c}7 \\
(13)\end{array}$ & $\begin{array}{c}15 \\
(22)\end{array}$ & $\begin{array}{c}13 \\
(21)\end{array}$ & $\begin{array}{c}12 \\
(19)\end{array}$ & $\begin{array}{c}1 \\
(4)\end{array}$ & $\begin{array}{c}1 \\
(4)\end{array}$ & $\begin{array}{c}1 \\
(4)\end{array}$ & $\begin{array}{c}1 \\
(4)\end{array}$ \\
\hline & Mean & $\begin{array}{c}6 \\
(8)\end{array}$ & $\begin{array}{c}23 \\
(26)\end{array}$ & $\begin{array}{c}38 \\
(39)\end{array}$ & & $\begin{array}{l}16 \\
(20)\end{array}$ & $\begin{array}{c}21 \\
(25)\end{array}$ & $\begin{array}{c}26 \\
(29)\end{array}$ & & $\begin{array}{l}13 \\
(15)\end{array}$ & $\begin{array}{c}16 \\
(19)\end{array}$ & $\begin{array}{c}20 \\
(23)\end{array}$ & \\
\hline $\begin{array}{l}\text { LSD } \\
(P<0.05)\end{array}$ & $\begin{array}{l}\text { Depth } \\
\text { Group } \\
\text { Depth } \times \\
\text { group }\end{array}$ & $\begin{array}{l}(8) \\
(8) \\
(14)\end{array}$ & & & & $\begin{array}{l}(5) \\
(5) \\
(8)\end{array}$ & & & & $\begin{array}{l}(4) \\
(4) \\
(7)\end{array}$ & & & \\
\hline
\end{tabular}

\footnotetext{
${ }^{a}$ Mean of four replicates and calculated as [ $\Sigma$ (no. plants in disease category) $\times$ (numerical value of disease category) $\left.\times 100\right] /[($ no. plants in all categories)
} $\times$ (maximum value on rating scale)]. Figures within parentheses are arcsine transformed means; there was no disease in noninfested control. 
seedling emergence in another experiment. These results strongly imply that these isolates may be serious pathogens of canola. Another $R$. solani group, AG 10, is collected regularly but at low frequency from the roots of cereals, lupins, and pasture species in Western Australia (12). It was confirmed that ZG9 is AG10 and may be a weak pathogen of cruciferous hosts (12). There was some evidence that with one isolate of ZG9, increasing the depth of sowing may increase its chance of causing hypocotyl rot. In this study, we isolated ZG9 from canola, and pathogenicity results are consistent with those reported by MacNish et al. (12). We observed that ZG9 was weakly virulent on canola, but there was a significant increase in hypocotyl and root rot as sowing depth was increased from 1 to 2 or $3 \mathrm{~cm}$. However, the lower virulence of ZG9 appears to limit the potential of this group to cause an economically significant problem in canola.

In Australian broadacre agriculture, canola is often grown in rotation with cereals and leguminous crops. Strains of Rhizoctonia that attack canola can be a potential risk to crops following canola, as our pathogenicity studies on different hosts indicated that ZG5, in addition to being a major pathogen of canola and mustard, was less but still significantly pathogenic to lupin and clover. Even if lupin and clover did not suffer serious damage from ZG5, they could provide a suitable host to maintain or increase ZG5 in soil, posing a threat to future mustard or canola crops. However, cereal hosts were found to be almost immune to ZG5, supporting earlier findings that ZG5 had weak to nil pathogenic activity on wheat (17). ZG1-1 caused severe root rot in all the hosts tested in our studies. Rhizoctonia bare patch disease caused by ZG1-1 in Western Australia has been previously reported on rapeseed (10) but not on canola. While we did not isolate ZG1-1 from canola, our data indicate that this strain could potentially be a major canola pathogen.

This is the first report of characterization of various zymogram groups of $R$. solani and Rhizoctonia species collected from canola in Australia. In conclusion, our studies show that ZG5 is the predominant and most highly pathogenic group and causes hypocotyl rot and postemergence damping-off of canola. Additionally, ZG11 , a bare patch causing group in cereals and legumes, can also cause serious root rot in canola. The known binucleate groups generally are less pathogenic on canola, although several unidentified binucleate types present in some situations could also cause hypocotyl rot on canola.

\section{ACKNOWLEDGMENTS}

We thank Jane Speijers for help with the statistical analysis and I. Riley, Senior Plant Pathologist, Agriculture Western Australia, for his critical review of the manuscript. We acknowledge with appreciation the Australian Grains Research and Development Corporation for providing financial support for this project.

\section{LITERATURE CITED}

1. Baird, R. E. 1996. First report of Rhizoctonia solani AG-4 on canola in Georgia. Plant Dis. 80:104.

2. Carling, D. E., Leiner, R. H., and Kebler, K. M. 1987. Characterization of a new anastomosis group (AG-9) of Rhizoctonia solani. Phytopathology 77:1609-1612.

3. Cruickshank, R. H. 1990. Pectic zymograms as criteria in taxonomy of Rhizoctonia. Mycol. Res. 94:938-946.

4. Gugel, R. K., Yitbarek, S. M., Verma, P. R., Morrall, R. A. A., and Sadasivaiah, R. S. 1987. Etiology of the Rhizoctonia root rot complex of canola in the Peace River region of Alberta. Can. J. Plant Pathol. 9:119-128.

5. Huber, D. M., Christmas, E. P., Herr, L. J., McCay-Buis, T. S., and Baird, R. 1992. Rhizoctonia crown rot of canola in Indiana. Plant Dis. 76:1251-1253.

6. Kaminski, D. A., and Verma, P. R. 1985. Cultural characteristics, virulence and in vitro temperature effect on mycelial growth of $R h i$ zoctonia isolates from rapeseed. Can. J. Plant Pathol. 7:256-261.

7. Kataria, H. R., and Verma, P. R. 1992. Rhizoctonia solani damping-off in oilseed rape and canola. Crop Prot. 11:8-13.

8. Keinath, A. P. 1995. Relationships between inoculum density of Rhizoctonia solani, wirestem incidence and severity, and growth of cabbage. Phytopathology 85:1487-1492.

9. Khangura, R., Barbetti, M. J., and Sweeting-ham, M. W. 1997. Association of Rhizoctonia species with hypocotyl rot and damping-off in canola. (Abstr.) Page 40 in: Proc. Bienn. Conf. Australas. Plant Pathol. Soc., 11th. Perth, WA.
10. MacNish, G. C. 1983. Rhizoctonia patch in Western Australia. Australas. Plant Pathol. 12:49-50.

11. MacNish, G. C., Carling, D. E., Sweetingham, M. W., and Brainard, K. A. 1994. Anastomosis group (AG) affinity of pectic isozyme (zymogram) groups (ZG) of Rhizoctonia solani from the Western Australian cereal-belt. Mycol. Res. 98:1369-1375.

12. MacNish, G. C., Carling, D. E., Sweetingham, M. W., Ogoshi, A., and Brainard, K. A. 1995 Characterisation of Anastomosis Group-10 (AG-10) of Rhizoctonia solani. Australas. Plant Pathol. 24:252-260.

13. MacNish, G. C., and Sweetingham, M. W. 1993. Evidence of stability of pectic zymogram groups within Rhizoctonia solani AG-8. Mycol. Res. 97:1056-1058.

14. Neate, S. M., Cruickshank, R. H., and Rovira, A. D. 1988. Pectic enzyme patterns of Rhizoctonia solani isolates from agricultural soils in South Australia. Trans. Br. Mycol. Soc. 90:37-42.

15. Nelson, B. D., and Christianson, T. 1995. Pathogenicity of binucleate Rhizoctonia AG-K on crops. (Abstr.) Page 80 in: Proc. Int. Sympos. Rhizoctonia, Facts Challenges Pathol., Taxon., Ecol. Dis. Control, June $27-$ 30, 1995. Noordwijkerhout, the Netherlands.

16. Sumner, D. R. 1974. Ecology and control of seedling diseases of crucifers. Phytopathology 64:692-697.

17. Sweetingham, M. W., Cruickshank, R. H., and Wong, D. H. 1986. Pectic zymograms and taxonomy and pathogenicity of the Ceratobasidiaceae. Trans. Br. Mycol. Soc. 86:305311.

18. Sweetingham, M. W., and MacNish, G. C. 1994. Rhizoctonia isolation, identification and pathogenicity: A laboratory manual. Misc. Publ. 14/92, Department of Agriculture, Perth, Western Australia. p. 30.

19. Tahvonen, R., Hollo, J., Hannukkala, A., and Kurppa, A. 1984. Rhizoctonia solani damping-off on spring turnip rape and spring rape (Brassica spp.) in Finland. J. Agric. Sci. Finl. 56:143-154.

20. Verma, P. R. 1996. Biology and control of Rhizoctonia solani on rapeseed: A review. Phytoprotection 77:99-111.

21. Yang, H. A., Sivasithamparam, K., and O'Brien, P. A. 1991. An improved technique for fluorescence staining of fungal nuclei and septa. Australas. Plant Pathol. 20:119120.

22. Yitbarek, S. M., Verma, P. R., and Morrall, R. A. A. 1987. Anastomosis groups, pathogenicity, and specificity of Rhizoctonia solani isolates from seedling and adult rapeseed/canola plants and soils in Saskatchewan. Can. J. Plant Pathol. 9:6-13. 